\title{
Securitization of Rights in Electronic Commerce Environment
}

\author{
Guo Peng \\ School of Law, Jinan University \\ Guangzhou, 510632 Guangdong
}

\begin{abstract}
Securitization of rights for paper-based securities is to integrate intangible rights with unique and tangible objects and the circulation of paper-based securities symbolizes the negotiability of rights. However, in electronic commerce, the essence of circulation of electronic securities is the control of the electronic transferable records, which is included in the legal relation of assignment of contractual rights. The purposes of this study is to analyze that transference of right of control of electronic transferable records has the same legal effect with the negotiability of traditional securities and further to make specific advice about legislation concerning electronic transferable securities in China. Trough making a comparison, logical analysis and value analysis, the paper draws following conclusions: it is two sides of the same coin to verify the legal controller of an electronic transferable record and to verify the uniqueness of the paper-based securities. Control of electronic transferable records and an assignment of right of control are functionally equivalent to possession, endorsement and delivery of paper-based securities. Therefore, the legality and validity of electronic securities shall be acknowledged by legislation in China.
\end{abstract}

Keywords-securitization of rights; electronic commerce; paper documents;Electronic Bills of Lading

I. NOMOLOGICAL ANALYSIS OF NEGOTIABILITY OF PAPERBASED SECURITIES

Bills of lading are typical examples of securitization of rights. The nature of trade of pursuing profits and high efficiency requires that the goods in shipment by sea can be resold. In order to realize the resale, the right to claim delivery of goods shall be transferred to the buyer of the goods in shipment. However, it will be very complicated to realize the transfer of rights through an assignment of a contract of shipment. According to the common principle of the Contract Law, the obligee is obliged to notify the obligor where the rights have been transferred. Therefore, the seller has to notify the carrier of change of the consignee every time the goods are resold, which will cost a large amount of time and money.

Obstacles of time and space have to be resolved in order to efficiently transfer the obligee's rights, so business credibility is in need for the sake of overcoming these obstacles. Paper is tangible and inexpensive while it can be written on and differentiated between an original and its duplicates, which makes it easy for businessmen to materialize the business creditability in the form of paper-based bills of lading. Consequently, the law abstracts the effect of assignment of contracts, but integrates the rights into paper-based bills of lading making the intangible rights materialized in the form of tangible paper-based bills of lading which are in the nature of uniqueness. Therefore, the aforesaid rights of the consignee become negotiable through negotiation of bills of lading. When rights are independent from the basic contractual relationship and are embodied in a physical form, and simultaneously the law endows this physical form with negotiability, it is said that the rights have been securitized. Other types of negotiable securities, such as negotiable instruments and warehouse receipts, are created based on the same principle [1]

As a kind of negotiable securities, the negotiability of bills of lading is mainly expressed in the way that the possession and transfer of paper-based bills of lading and the possession and transfer of the goods have an equal effect, so bills of lading can be circulated between the assignor and the assignee freely without having to notify the obligor, namely the carrier, or asking the obligor for agreement. A bill of lading is a proof for the carrier to verify the possessor or owner of the goods, so instead of authenticating the identification of a holder of a bill of lading, the carrier only need to authenticate the bill of lading. In an environment with paper being the carrier of information, securities are described as "written proofs made for the purpose of certifying or defining rights". Bearing this concept in mind, people always regard securities as combinations of rights and paper proofs or documents while rights of securities can be divided into a dual structure: the obligee's ownership of a paper proof and rights indicated in the paper proof. The existence of rights indicated on or in securities depends on their physical carriers, while the obligee's ownership of paper-based securities is a precondition for having rights specified on or in the securities [2].

In a transaction using paper documents, the realization of the negotiability of securities relates closely to their physical paper carriers because a tangible document is a must in order to embody the rights indicated on or in securities and the rights need to be integrated with the physical securities. Therefore, the law requires that the securities shall have originals for the purpose of verifying integrity and authenticity of content of rights. It is also required by law that securities shall be of uniqueness so the assignee of a security can make sure that it is the only legal holder of the security. In this way, parties involved in the transaction are given a reliable guarantee of security safety while the obligor can confirm the rightful obligee when performing its duty. 
The essence of negotiable securities is securitization of property rights and creditor's rights. With abstract rights recorded on paper-based securities, rights indicated on the papers can be transferred through a simple transfer of rights of possession of physical securities. Securitizations of rights can simplify procedures of transferring property rights and creditor's rights, which facilitates developments of transactions. From the standpoint of nomology, negotiable securities are regarded as transfers of contracts approved by law. They are commitments in writing and the interests indicated in the contracts can be transferred in this way, namely the assignee of the rights can claim performance of commitments without notifying the carrier of the transfer of interest in advance [3].

\section{CiRCULATION MECHANISM OF ELECTRONIC BILLS OF LADING}

\section{A. Circulation mechanism of CMI Rules for Electronic Bills of Lading}

In 1990, International Maritime Committee (CMI) made Rules for Electronic Bills of Lading, which adopts a system working on the basis of carrier's functions. The core of the system is that it designates the carrier to issue an electronic bill of lading and meanwhile provides a registration mechanism for transfer of an electronic bill of lading which is controlled by the carrier. The CMI Rules is carried out around functions of the private key since the holder of a private key has a series of rights including claiming delivery of the goods, nominating a consignee, substituting a nominated consignee for any other party, instructing the carrier on any other subject concerning the goods and transferring the right of control and transfer to another party. The legal status of a holder of a private key is equivalent to a holder of a paper-based bill of lading.

A basic procedure of the Rule is as follows: the carrier, upon receiving the goods from the consignor, shall give notice of the receipt of goods to the consignor by a message at the electronic address of the consignor, in which shall include the name of the consignor, the description of the goods, the date and place of the receipt of the goods, a reference to the carrier's terms and conditions of carriage and a private key. After the consignor confirms the receipt of message to the carrier, the consignor shall be the holder of the bill of lading and the private key. In the event that the current holder of the private key intends to transfer the Right of Control and Transfer to another party, the holder is obliged to notify the carrier of its intention to transfer its Right of Control and Transfer. Verifying the authenticity of the notification, the carrier shall transmit the aforesaid information except the private key to the proposed assignee. If the proposed assignee advises the carrier of its acceptance of the Right of Control and Transfer, the carrier shall cancel the current private key and issue a new one to the assignee, thus the assignee being the new holder. After the goods arrived at the port of destination, the carrier shall deliver the goods to the last holder of the private key [4].

\section{B. Bolero Rules}

Bolero, namely Bill of Lading Electronic Registry Organization, is legally an attorney of carriers. It functions mainly based on a core telecommunication platform and a tile registry. The telecommunication platform provides a messaging infrastructure for all involved parties in international trades to exchange information while the title registry plays a role of storing records of registration of holders of electronic bills of lading and managing relationships of rights and liabilities concerning the bills of lading amongst involved parties. In the Bolero system, when the carrier intends to issue an electronic bill of lading to the consignor, it should upload an electronic message to the core telecommunication platform, in which same content as a traditional paper-based bill of lading shall be included, and it should note that the message is addressed to the consignor. Confirming receipt of this message, the platform will verify whether the message is authentic, unique and being in initial condition prior to signing it digitally and forwarding it to the consignor, whereupon the consignor will be registered as the holder of the electronic bill of lading with the title registry. If the consignor intends to transfer the bill of lading to one of involved parties, such as the bank, the consignor needs to send an instruction of transfer to the platform. Upon receipt of this instruction, the platform will authenticate it according to the records in the title registry. Then the platform will transmit the instruction with its digital signature to the bank, updating the bank as the new holder of the electronic bill of lading with the title registry. Other procedure regarding transfer will be processed in the same way.

\section{NOMOLOGICAL ANALYSIS OF ASSIGNMENT INSTEAD OF} NEGOTIABILITY

As mentioned above, electronic bills of lading and paperbased bills of lading are intrinsically different in respect of the method of circulation. The mechanism of registration or verification of control on electronic bills of lading which is set up by the carrier or its attorney must track every transaction of electronic bills of lading, confirming the new legal holder every time an electronic bill has been transferred. Upon arrival of the goods at the port of destination, the carrier verifies the holder's identity through the private key or registry records before delivering the goods to the holder and the consignee should prove its identity as the holder of the electronic bill of lading with the private key before being taking the delivery.

Paper-based bills of lading are negotiable which can be circulated amongst the assignors and assignees without the carrier being notified of the transfers. A paper-based bills of lading, as a kind of negotiable securities, is a proof for the carrier to verify the owner of the goods. A paper-based bill of lading is tangible, unique and has to be an original not a unauthorative copy, which ensures that every batch of goods are paired with exactly one paper-based bill of lading. Given it, the right to take the delivery can be attached to the paper-based bill of lading thus realizing the securitization of the right. Therefore, as provided in law, paper-based securities symbolize the rights with a piece of paper, forming one-to-one correspondence between papers and the rights. One specific piece of paper is in the exclusive nature and possession of this paper equals possession of an exclusive right. In this way, the paper is endowed with values and people can exercise the rights using the specific paper accordingly.

In the environment of Internet, it is information other than tangible things that can be transmitted. Electronic bills of lading, as a kind of electronic information, can be copied 
infinitely and can be presented in any physical space at the same time. Therefore, the notions of uniqueness and original lose their significance in electronic environment. Article 9 of The United Nations Convention on International Carriage of Goods Wholly or Partly by Sea provides that one of procedures for the use of negotiable electronic transport records including electronic bills of lading is that the holder shall be able to demonstrate that it is the holder. Similarly, The Draft Model Law on Electronic Transferable Records, drafted by the Unite Nations Commission on International Trade Law, indicates that electronic transferable records (including electronic bills of lading) might not be capable of determining the rightful person in control on their own [5]. Therefore, it can be inferred that electronic bills of lading do not have an important function as paper-based bills of lading do since a paper-based bill of lading is employed for the carrier to verify the owner of the goods it carried and the carrier only need to verify the authenticity and legality of the paper-based bill of lading when delivering the goods, not having to verify the identity of the holder.

But with respect to electronic bills of lading, it is important to confirm the legality of one party's possession of and control on an electronic bill of lading. And as long as it can be ensured that only one party is entitled to have the right of control, the electronic bill of lading is unique just as a paper-based bill of lading is. Therefore, the circulation of electronic bills of lading actually is a process of controlling the continuous assignments of bills of lading among involved parties, which requires verifying legal identities of the holder or the assignee and enabling the carrier to confirm the rightful person who has the right of control of the electronic bill of lading at any point of time.

The mechanism of control and registration of electronic bills of lading tracks every transaction of an electronic bill of lading, so that the carrier or its attorney is able to confirm the rightful assignee or controller after the electronic bill of lading has been transferred. In other words, every time the goods symbolized by the electronic bill of lading are resold, the carrier, as the obligor, has to understand that the consignee has changed. Therefore, when the assignee, namely the obligee, has made assignment of its rights, it shall notify the carrier of the new holder who has obtained the right to claim the delivery. In this way, the circulation of electronic bills of lading returns to the legal relation of assignment of contractual rights. In fact, article 5 of the third chapter in Bolero Rulebook explicitly points out that transfer of electronic bills of lading is completed through novation of the contract of carriage. Upon the acceptance by the new holder of the electronic bill of lading of its designation, a contract of carriage shall arise between the carrier and the new holder and the new holder shall be entitled to all the rights and liabilities of the contract of carriage while rights and liabilities of its prior designee, namely the assignor, under its contract of carriage with the carrier shall immediately cease and be extinguished.

Having characteristic of specificity and uniqueness, the paper-based securities are combined with rights, so transfer of rights takes effect simultaneously when paper-based securities are transferred, thus realizing securitization of rights. It is a sensible institutional design to endow paper-based bills of lading with negotiability as securities. However, circulation of electronic bills of lading should be applied to the legal relation of assignment of contractual rights because electronic bills of lading are not traditional negotiable securities since they cannot conform to conditions of being sole and having original copies but using electronic bills of ladino can take full advantages of electronic data exchange and save considerable time compared with traditional circulation of paper-based documents. Therefore, in electronic commerce, it is also a pragmatic and advisable choice to negotiate electronic bills of lading by means of assignment of contractual rights with consent of.

\section{LEGISLATION FOR ELECTRONIC SECURITIES UNDER THE FUNCTIONAL EQUIVALENCE PRINCIPLE}

To confirm the holder (the controller) and to verify the uniqueness of securities are two sides of a coin. The reason why a security can be regarded as unique and valid is that its holder is a legal holder (controller) and vice versa. In transaction environments with documents in paper form, the key point is to verify the uniqueness and authenticity of securities. On the contrary, in electronic environments, the key point is to verify the authenticity and legality of the holder's identity [6].

In chapter 3 of The United Nations Convention on International Carriage of Goods Wholly or Partly by Sea defines substitutability between negotiable electronic transport records and negotiable transport documents, recognizing the legality of use of the electronic transport records. Article 8 of the Convention with respect to use and effect of electronic transport records states the principle of functional equivalence of electronic transport records. An electronic transport record and a transport document have the same effect with respect to provided that the issuance, control or transfer of an electronic transport record is with the consent of the carrier and the consignor. Exclusive control of an electronic transport record has the same effect as the possession of a transport document.

§ 7-106 of Article 7 "Documents of Title" of Uniform Commercial Code interprets the dialectical relationship of control of electronic document of title and the document's uniqueness. §7-106 (a) provides that a person has control of an electronic document of title if a system employed for evidencing the transfer of interests in the electronic document can reliably prove that person as the person to which the electronic document was issued or transferred. And paragraph (1), (4), (5) and (6) in §7-106 (b) define the uniqueness and integrity of electronic document of title. It is provided that any amendments or copies that change or are added to the authoritative electronic document of title shall be made with the consent of the controller and copies of authoritative copy must be readily identifiable as a copy not the original document Meanwhile, paragraph (2) and (3) defines the rightful controller of the authoritative copy whose identity shall be as the same as the person indicated by the authoritative [7]. Transfer of the right of control of electronic securities is completed through agreed transfer of contractual rights, which is a functional equivalent of endorsement and delivery of paper-based securities.

According to official comments on Article \$7-106 of American Uniform Commercial Code, the notion of "control of 
electronic documents of title" is a replacement of notions of "possession" and "endorsement" within the scope of tangible document of title. Paragraph (a) of $\$ 7-501$ regarding negotiation of electronic document of rights provides that if a negotiable tangible document of title circulates as per the order of a named person, the document is negotiated by the named person's endorsement and delivery. Paragraph (b) provides that if a negotiable electronic document of title runs to the orders of a named person, the document is negotiated by delivery of the document to another person while endorsement by the named person is not required in the process of negotiation [8]. Although electronic securities are not in physical forms as paper-based securities are but exist in the form of electronic documents of title, having no uniqueness as tangible documents have, the authority and authenticity of electronic documents of title can be guaranteed as long as a person can be reliably established as the legal controller and any amendments or copies that change or are added to the authoritative electronic document of title are required to be made with the consent of the controller.

The Draft Model Law on Electronic Transferable Records uses "electronic transferable records" to summarize negotiable documents or notes in electronic commerce, such as drafts, cheques, promissory notes, bills of lading, warehouse receipts and other negotiable securities. Article 7 of this draft stipulates that where the law requires that information should be in writing, that requirement is met with respect to an electronic transferable record if the information contained therein is accessible so as to be usable for subsequent reference [9]. Article 8 stipulates that where the law requires a signature of a person, that requirement is met with respect to an electronic transferable record if a reliable method is used to identify that person and to indicate that person's intention in respect of the information contained in the electronic record [10]. Article 9 states that where the law requires a transferable document or instrument, that requirement is met by an electronic record if a reliable method is used to render that electronic record capable of being subject to control from its creation until it ceases to have any effect or validity. This article intends to provide a functional equivalence rule for the use of transferable documents or instruments, aiming at combining the two prevalent approaches, namely "singularity" and "control". Through resorting to the notion of "control", it is possible not to refer to the notion of "uniqueness", which posed technical challenges. In the context of electronic transferable records, the reason why a functional equivalence rule is offered is to avoid multiple claims for performance. Therefore, there is no need to include a functional equivalence rule for "original" in the draft provisions [11]. Article 17 sets forth control of an electronic transferable record as the functional equivalent of possession of a paper-based transferable document or instrument and transfer of right of control of an electronic transferable record as the functional equivalent of delivery, i.e. transfer of right of possession of a paper-based transferable document or instrument [12]. Article 19 provides that where the law requires the endorsement in a paper-based transferable document or instrument, that requirement is met with respect to an electronic transferable record if information constituting endorsement is that electronic transferable record and that information complies with the requirements regarding signature and integrity set forth in articles 8 and 9 [13]. Article 18 states that where the law requires a person to present a paper-based transferable document or instrument, that requirement is met with respect to an electronic transferable record by the transfer of an electronic transferable record to the obligor, with endorsement if required [14].

\section{CONCLUSION}

It can guarantee the authority and uniqueness of an electronic document of title or an electronic transferable record when a person can be identified as the controller of an electronic document or transferable document and be endowed with right of control. Transfer of electronic documents of title or transferable records represents the transfer of rights. In securities law, the function of the physical form of securities is mainly to symbolize the transfer of rights, facilitating transfer of rights. Compared with rights indicated on paper-based securities, only the medium other than the nature of rights indicated in electronic securities change. Therefore, electronic securities can also symbolize the rights and the securities remain negotiable when the delivery of securities is completed using electronic documents of title or electronic transferable records [15].

The holder of paper-based securities is presumed as the obligor and a person controlling the electronic document of title or an electronic transferable record can be presumed as the legal obligor. Electronic documents of title or electronic transferable records can symbolize citizens' rights as paperbased securities, which alters the traditional concept of negotiable securities so securities or rights indicated in or on securities has not been connected merely with the paper-based form [16].

Article 10 of The United Nations Convention on International Carriage of Goods Wholly or Partly by Sea acknowledges that transferable transport documents and transferable electronic transport records can substitute for each other. §7-105 of The Uniform Commercial Code stipulates that tangible documents of title and electronic documents of title can replace each other, which reflects the equal legal status of them. Meanwhile, Article 6 of The Draft Model Law on Electronic Transferable Records states that an electronic transferable record shall not be denied legal effect, validity or enforceability on the sole ground that it is in electronic form [17]. Considering the above, it is a critical problem to be solved for Chinese business legislation to adjust the existing Chinese legislation regarding drafts, cheques, promissory notes, bills of lading and warehouse receipts to needs of e-commerce by means of referring to existed relevant legislation and establishing appropriate rules and regulations.

The paper proposes that Chinese rules of negotiable electronic securities can include following stipulations: (1) Where a transferable electronic record is issued as per the issuer's request, it has the same functions and effects as the paper-based securities or instruments have and law regarding traditional negotiable securities and instruments is applicable to transactions this electronic record involves. (2) Where a person is verified as the one to whom the record electronic transferable records, the person has control of an electronic transferable record. (3) There is only one single authoritative copy of the 
electronic record. Any amendments or copies that change or add the identified assignee of the authoritative copy shall be made with consent of the controller and any amendment of the authoritative copy is readily identifiable as authorized or unauthorized by the controller. Each copy of the authoritative copy and any copy of a copy is readily identifiable as a copy that is not the authoritative copy. (4) The controller of transferable record and the holder of paper negotiable securities have the same legal status.

\section{ACKNOWLEDGMENT}

Author: Guo Peng, Professor of Law School of Jinan University, Doctor of Law.

\section{REFERENCES}

[1] Chen, Fang and Jianyuan Zheng. "On Legal Nature of Bills of Lading." Law Review 2011(4) : P63

[2] Xie, Huaishi. Essence of Law of Bills. Beijing: Law Press, 1990: P5-6

[3] Guest A.G.. British Contract Law and Case, Beijing: Chinese Encyclopedia Press. 1988: P418

[4] Emmanuel T. Laryea. "Paperless Documents: An Australian Perspective". Tulane Maritime Law Journal, 2010, winter: P128

[5] Official Records of the United Nations Commission on International Trade Law by Working Group IV (Electronic Commerce), Fifty-third sessions, Supplement No. 17(A/CN.9/WG.IV/WP.137): para.23

[6] Wu, Huanning, An Interpretation of the "Rotterdam Rules": The United Nations Convention on Contracts for the International Carriage of Goods Wholly or Partly by Sea, Beijing: China Business Press. 2011:P37
[7] American Law Institution, The Uniform Commercial Code and its Official Comments (2nd volume), Beijing: Renmin University of China. 2005: P362.

[8] American Law Institution, The Uniform Commercial Code and its Official Comments (2nd volume), Beijing: Renmin University of China. 2005: P410

[9] Official Records of the United Nations Commission on International Trade Law by Working Group IV (Electronic Commerce), Fifty-third sessions, Supplement No. 17 (A/CN.9/WG.IV/WP.137): para.44

[10] Official Records of the United Nations Commission on International Trade Law by Working Group IV (Electronic Commerce), Fifty-third sessions, Supplement No. 17 (A/CN.9/WG.IV/WP.137): para.47

[11] Official Records of the United Nations Commission on International Trade Law by Working Group IV (Electronic Commerce), Fifty-third sessions, Supplement No. 17 (A/CN.9/WG.IV/WP.137): para.52

[12] Official Records of the United Nations Commission on International Trade Law by Working Group IV (Electronic Commerce), Fifty-second sessions, Supplement No. 17 (A/CN.9/WG.IV/WP.135/Add.1): para.19

[13] Official Records of the United Nations Commission on International Trade Law by Working Group IV (Electronic Commerce), Fifty-second sessions, Supplement No. 17 (A/CN.9/WG.IV/WP.135/Add.1): para.35

[14] Official Records of the United Nations Commission on International Trade Law by Working Group IV (Electronic Commerce), Fifty-second sessions, Supplement No. 17 (A/CN.9/WG.IV/WP.135/Add.1): para.28

[15] Ye, Lin and Zhang Hao. "The connotation and Legal Status of Paperless Securities." Academic Journal of Henan University, 2009(2):P27

[16] Ye, Lin. Securities Law. Beijing: Renmin University of China, 2008: P5

[17] Official Records of the United Nations Commission on International Trade Law by Working Group IV (Electronic Commerce), Fifty-third sessions, Supplement No. 17 (A/CN.9/WG.IV/WP.137): para.42. 